\title{
Augmented learning - spreading your wings beyond the classroom
}

\author{
Vickel Narayan*, Catherine Davis and Robin Gee \\ Te Puna Ako, Unitec Institute of Technology, Auckland, New Zealand
}

(Received 19 March 2012; final version received 13 June 2012)

\begin{abstract}
The dramatic advancements in technology over the last 5 years have created an environment that could support learning that surpasses anything we would have seen, experienced or imagined before. While new technologies offer considerable opportunities for improved learning, their use however has remained as a plug-on to traditional teaching methods. In this article, we discuss the impact of reinvigorating two courses where the use of Mobile Web 2.0 (MW2.0) tools was embedded within the learning process with an aim of enabling learner-generated content and context. Students and staff in this collaborative project, from two different courses, were equipped with iPhone $4 \mathrm{~s}$ and iPad $2 \mathrm{~s}$ for the duration of the course ( $n=36,16$-week semester). A participatory action research method was used to evaluate the project and to scaffold the staff into learning and teaching in the twenty-first century. The pedagogical approach underpinning this project and the design for use of MW2.0 tools are discussed. Examples of artefacts created by the students in the project are outlined and provide an overview of the different contexts students interacted in.
\end{abstract}

Keywords: Pedagogy 2.0; learner-generated content; learner-generated context; social constructivism; Mobile web 2.0

\section{Introduction}

This project was a collaboration between students and staff from two level four courses - Digital Media (offered by Department of Communication Studies) and Moving Images World (offered by Department of Performing and Screen Arts). The Digital Media course focused on exploring the impact of new and emerging forms of media on communication (for example YouTube, Twitter and blog), while the Moving Images course focused on exploring new and emerging technologies for creating "moving images" for communication purposes. These courses have been taught in collaboration with each other for the last 2 years. The teachers, however, through their own experience and reflections, felt there could be more that could be done to help the students who enrolled in these courses. As a result they consulted the academic development unit (Te Puna Ako) to help explore the issues and opportunities.

The researchers held a pre-project planning meeting with the teachers to understand the coverage and requirements of the course, the prevalent teaching methods and the tools that were being used. As a result, three major problematic areas were identified: course facilitation, choice of tools for use in the course and the limited access to specialist equipment needed by the students. While the issues are

*Corresponding author. Email: vnarayan@unitec.ac.nz 
highlighted separately, it was the complex combination of all three elements that created issues and needed revisiting.

Over the last 2 years the students had used a Spruz site (a social networking platform) and Moodle (a learning management system) as a learning portal and for managing group projects. Students had one 3-hour lab session per week booked for working on group projects and tasks. The students also only had limited access to specialist equipment in the filming studio. Access to resources such as specialist equipment in the filming studio was limited, which was another impediment to the way the course was facilitated. The course teachers were aspiring towards creating an interactive, engaging and collaborative learning environment apart from the lecture sessions, but the lab hours were more about achieving the required skills and knowledge. While the design of these courses was theoretically underpinned by social constructivist pedagogies, this did not translate into practice.

\section{Literature}

The rapidly advancing technologies often "tickle" the educators and other important stakeholders in education (Saettler 1990). Technology in education is mostly viewed as a plug-in or a supplement to traditional teaching methods and practices in the classroom (Amiel and Reeves 2008; Bender 2003; Reeves 1997; Siemens and Matheos 2010). Amiel and Reeves (2008) argue that when we consider technology, we talk of it as a product or what it can do. They argue that it is this common perception of the term "technology" that limits its effective use in education. Instead, they propose that rather than looking at technology as a product, to think of technology as a process. When technology is viewed as a process, it validates the reasons "why" it is being considered and how it will be used hence pedagogy becomes the focus (Amiel and Reeves 2008).

\section{Defining Mobile Web 2.0}

The term Web 2.0 was coined in 2004 by Tim O'Reilly (Anderson 2007) and refers to the second generation of the Internet "or more personalized, communicative form of the World Wide Web that emphasises active participation, connectivity, collaboration and sharing of knowledge and ideas among users" (McLoughlin and Lee 2007, p. 665; O'Reilly 2005; O'Reilly and Battelle 2009).

Mobile Web 2.0 in this study is defined as Web 2.0 tools that are configured/ designed to function over mobile devices such as phones, smartphones or tablets (Cochrane and Bateman 2010). The advancement in handheld devices and the ever-growing processing power of these devices has fuelled the growth of Web 2.0 tools (Dabbagh and Reo 2011; TLRP 2008). Mobile handheld devices provide the capability of staying connected with the rest of the world through cellar $3 \mathrm{G} / 4 \mathrm{G}$ network. The Web 2.0 tools when used on these devices allow the user to share their experiences with whomever they choose to at ease, thus amplifying the Web 2.0 effect.

Pedagogy 2.0 outlines the potential use of Web 2.0 tools in education which advocates active learner participation (communication, collaboration, community and connectedness), productivity (learner-generated content, creativity and innovation and distribution/creation of knowledge) and personalisation (learner choice, customisation, ownership and self-regulation) as the key to effective use (McLoughlin and Lee 2008a; McLoughlin and Lee 2008c). Pedagogy 2.0 is firmly 


\section{Narayan et al.}

grounded in social constructivist, socio-cultural pedagogies (Vygotsky 1978, 1986) and contemporary pedagogies such as connectivism and heutagogy (Blaschke 2012; McLoughlin and Lee 2008a; Siemens 2005) which emphasise the importance of active, collaborative, self-determined and social learning. Pedagogy 2.0 utilises the affordances of Web 2.0 tools such as creation and co-creation of knowledge, communication, collaboration, user empowerment and ubiquitousness to create a virtual environment in which students can learn. (McLoughlin and Lee 2008b, 2008c).

While Web 2.0 tools enable learner-generated content, Web 2.0 tools used on mobile handheld devices enable bridging of different learning contexts (bridging between a teacher controlled classroom (formal) and learning driven by the student outside the classroom (informal context) (Cochrane and Bateman 2010). The ubiquitous nature of mobile devices and connectivity facilitates learnergenerated context defined as the learners interaction with the surrounding (virtual online spaces or physical spaces) of his/her choice or the learners interaction with a collection of resources such as digital artefacts, people and other objects curated by the teacher, another individual or a community to further its own learning (Luckin 2008; Luckin et al. 2007; Luckin et al. 2008a, 2008b).

\section{Design}

All students involved in the project were issued an Apple device for use in the course. The Moving Images (MI) students were issued with iPhone 4s and the Digital Media (DM) students were issued iPad $2 \mathrm{~s}$ for use. The devices were selected for its appropriateness to tasks the students in the two courses had to perform. The two staff teaching the courses were also issued iPhones and iPads.

Figure 1 outlines the role of the researcher in the project with the students and staff. The researcher spent 3 hours in the first week helping students set up their blog and Twitter accounts. The students were also given an overview of the mobile device they were going to use. This included using the device to take pictures, videos and blogging using the Wordpress application and sending a tweet using the Twitter application. Students were also taken through a tutorial on how to create an Apple account and how to download and install applications on the mobile devices.

The researcher provided 1 hour of technological support to the students on a weekly basis (A in Figure 1) or as needed. Similarly the researcher provided technological and pedagogical support to the staff involved in the project on weekly

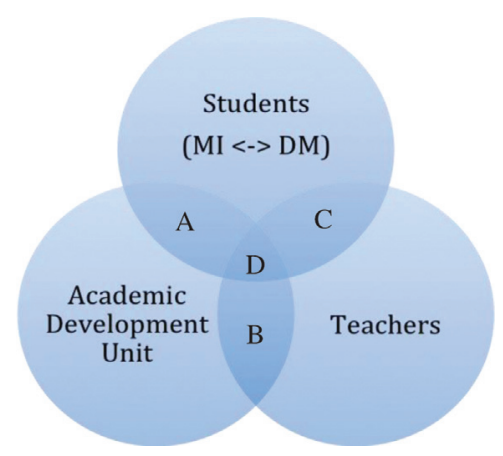

Figure 1. Community driven scaffold for use of mobile devices in learning and teaching. 
bases or when needed (B in Figure 1). Pedagogical and technological support to the staff was deemed necessary, as neither staff had used smart devices in education before. This pedagogical and technological knowledge enabled the staff to embed the use of MW2.0 tools in facilitating learning and teaching ( $\mathrm{C}$ in Figure 1). The researcher's role in supporting and scaffolding both students and staff for the duration of the project ensures that the MW2.0 tools are used effectively (D in Figure 1).

The concept map (Figure 2) outlines the intended use of the MW2.0 tools in the course by the students and teachers. The use of the mobile device in the project is underpinned by social constructivist pedagogies where learners are actively involved in creating new knowledge together, thus learner-generated content is an outcome in the course.

For the MI students, the mobile devices provided a portable studio for taking, editing and sharing videos and pictures. This also gave them the opportunity to practice, refine and master their production skills at anytime and any place. Vastly different from the timetabled weekly slots in the production studio where creativity was confined within the four walls in the room. The DM students also benefited from these arrangements as they got to experience and evaluate the impact of new and emerging types of media on communication as such mobile videos/audios, blog and Twitter compared to reading about these tools to gain an understanding prior to this project.

\section{Methodology}

A participatory action research (PAR) defined as "collective, self-reflective enquiry undertaken by participants in social situations in order to improve the rationality and justice of their own social practices" (Kemmis and McTaggart 1988, p. 5) was used as

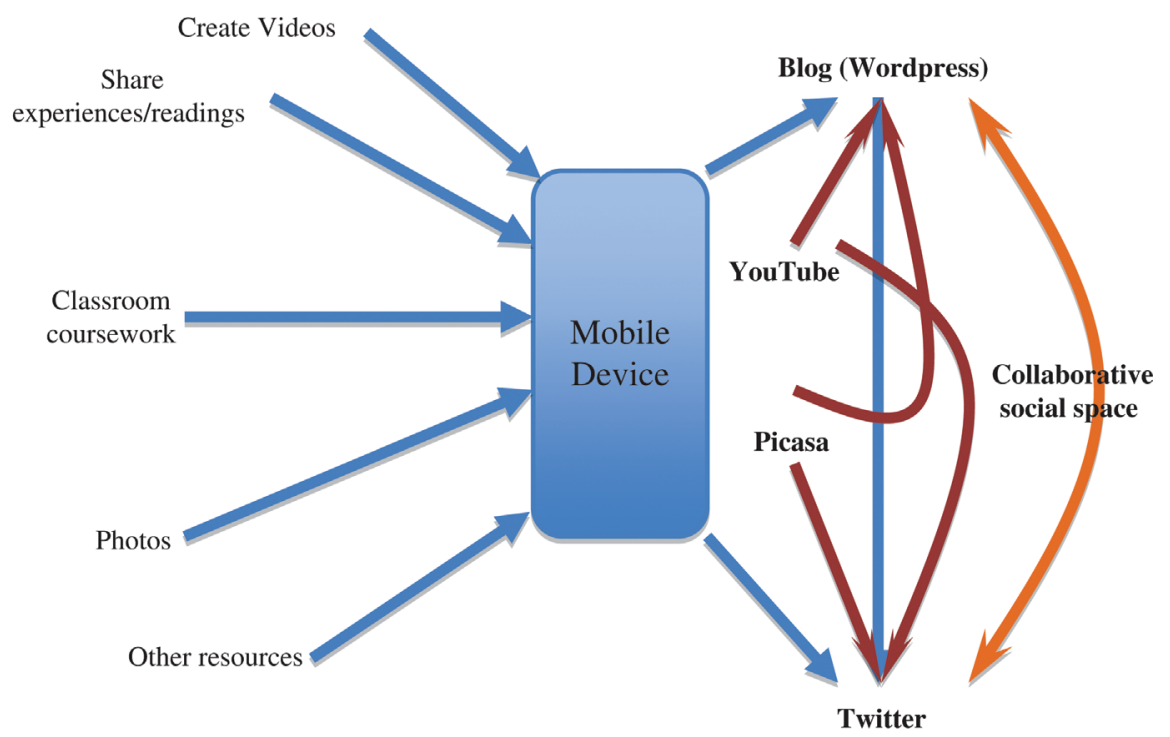

Student-generated content

Mobile Device

Web 2.0 tools

Figure 2. Concept map for the use of MW2.0 tools. 


\section{Narayan et al.}

an evaluative method in this study. The collaborative and participatory nature of PAR helps build a community (McNiff 1988) in this case with the students and staff over the duration of the study. The PAR method allows the researchers to work alongside the students and staff as a member of the community in helping improve their pedagogical and technological knowledge and at the same time evaluating the impact of MW2.0 (data collection). The staff teaching these courses were relatively new to the use of MW2.0 in education and were interested in exploring and evaluating the use in this pilot study.

\section{Data collection}

The data in this project were collected at three stages of the project and consisted of:

- A pre-project focus group with the teaching staff focusing on the issues faced with previous students.

- A survey administered at the start of the course to establish what experience students had with MW2.0 tools.

- Data from student blogs, Twitter posts and student created artefacts was also elicited, mainly showing student reflections on their experience in the course. The researcher's secondary role in the project was data collection from the weekly meetings with staff and students. This data were collected to identify how MW2.0 tools were being used.

- A post-project student survey and focus group was conducted with volunteering students. And an end of the project interview with the two staff was conducted. This data were collected to identify student and staff attitude towards the use of MW2.0 in learning and how the MW2.0 tools were used.

\section{Results}

\section{Pre-project survey}

The survey conducted at the start of the course provided an overview of the type of devices the students had and Web 2.0 tools they had interacted with prior to joining the course. Figure 3 highlights that $64 \%$ of the students $(n=36)$ had access to a desktop computer at home that had Internet connectivity. Eighty-nine per cent of the students had viewed videos on YouTube but only 25\% of the students had uploaded anything. Twitter was the highest used social media out of all the social platforms surveyed but mainly for entertainment purposes (following celebrities and major shoe and clothing brands). Only $16 \%$ of the students in the class had a blog. The preproject survey data outlined that students were mainly content consumers and their use of the resources was entertainment focused.

\section{Use of MW2.0 tools in the course}

Twitter and blogs were used as primary tool for students and staff to communicate, share resources and ideas. A Twitter hashtag (\#commpasa11) was established for use in the course by the students and staff. Student Wordpress blogs were configured to auto-tweet every time the students blogged. A total of 633 tweets were sent by the students and staff during the project with this hashtag. This count excludes any tweet 


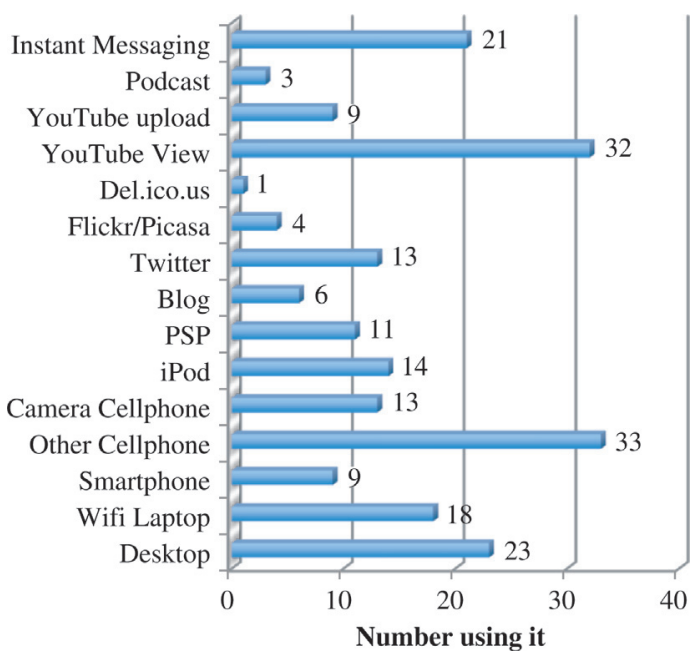

Figure 3. Student devices and use of Web 2.0 tools.

that was sent between students and staff without the hashtag. An analysis of the tweet sent by the staff and students can be found here http://archivist.visitmix.com/ vnarayan $/ 1$.

Figure 4 provides an overview of how the hashtag was used during the course. Students and staff used the hashtag frequently at the start of the course and the use slowly declined after the first few weeks. One possible explanation for why the use of the hashtag declined after a month could be that the students and staff started following each other effectively forming an online community, an aspect that was encouraged in the course. An analysis of top tweeting student Twitter profiles showed a majority $(87 \%, n=15)$ of them followed field leaders on Twitter thus widening their learning network.

\section{Student ownership, content and context}

This section of this article outlines how and in what context the students made use of MW2.0 tools in their learning. The results also highlight the degree of control the students had in determining how they learned, the location of their learning and the time at which they learned.

The students in this study formed groups of four consisting of members from both courses. The students self-elected themselves in the group after hearing and

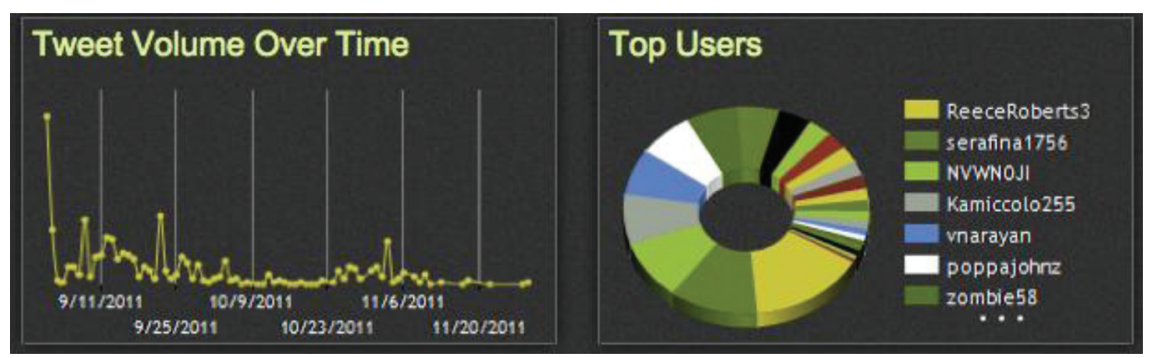

Figure 4. Tweet statistics from the course with \#commpasa11 hashtag. 


\section{Narayan et al.}

voting on project ideas pitched by the MI students. This ensured that the MI students would get an opportunity to create media as outlined in the course document and the DM students would get to evaluate the impact of using different media (blog, Twitter and any other media the students were interested in) on communication within the group and the wider class community.

As a result, nine groups were formed. The groups worked on nine different projects that they themselves pitched (http://youtu.be/U4Bd1VPh0lo). An overview of five projects, the use of web tools and the contexts the students chose to work in are discussed below.

The five projects nicknamed, (1) The Ghost Story, (2) Transport, (3) Growing up, (4) Wings and (5) Homeless, are events that were captured through the use of MW2.0 tools. The camera found on the iPhone and iPad and other social media possibilities were used extensively in these group tasks. Students having the affordance enabled by MW2.0 chose to document or tell real world stories.

The Ghost Story, was filmed in Building 1 of the campus that was built in 1865 and was used as an asylum for psychologically ill people. There are rumours that this building is haunted. The students took to this idea and filmed a small episode featuring students as cast from other groups. The Transport project stemmed from the experience of a student during the Rugby World Cup. When thousands of people were left stranded on the train stations and hundreds were stuck in a train attempting to get to the opening ceremony. The group focused their project on the perils of travelling to the campus on a train. The plot for Growing Up comes from a sister watching her younger brother grow up in a digital world, where the life of youngsters are surrounded by interactive media mainly video games. The Wings project features a student at her study desk at home, struggling to finish the essay she is writing and is in desperate need for inspiration. And the Homeless project is an enactment of a life of a homeless, alcoholic and addicted gambler, and her struggles in life.

Table 1 highlights the contexts and content students created during these projects.

\section{Post-survey, focus group and staff interview}

Thirteen students took part in the voluntary end of project survey. An overwhelming number of students $(92 \%, n=13)$ agreed that the use of MW2.0 tools in the course was fun, easy to use, helped them with group tasks. Ninety-three per cent of the students either agreed or strongly agreed that the method and tools used helped increase the quality of learning, was comparatively better then their previous learning experience and made communication and receiving feedback from peers and the lecturers easier.

The eight students who took part in the post-project focus group commented on the usefulness of the MW2.0 tools in their learning and appreciated the opportunity to experience the $3 \mathrm{G}$ network and connectivity. They outlined that quick access to information anytime and anywhere, and ability to collaborate, communicate and create as having positive impact in their learning. Students in the focus group also commented that because of MW2.0 tools the issues they had with not having access to specialist equipment was not problematic. In fact in their view, this setup was more productive and effective than the studio model. It allowed them the opportunity to put their understandings into practice whenever he/she wanted, without any limitations of the context they were in. A common feedback from the students in the project was that it was a fun experience and they got to be creative and innovative in their approach. 
Table 1. Student-generated context and content.

\begin{tabular}{|c|c|c|c|}
\hline Project & Physical context & Virtual context & Project output \\
\hline Ghost story & $\begin{array}{l}\text { On-campus } \\
\text { building } 1\end{array}$ & $\begin{array}{l}\text { Twitter - a group hashtag } \\
\text { (http://archivist.visitmix. } \\
\text { com/vnarayan/4) } \\
\text { Foursquare - Geo-tagging } \\
\text { rooms with information } \\
\text { prior to filming } \\
\text { Storyboarding app on } \\
\text { the iPad } \\
\text { - Video logs and blog posts }\end{array}$ & $\begin{array}{l}\text { http://youtu.be/FJ4iD } \\
\text { L6ekPA }\end{array}$ \\
\hline Transport & $\begin{array}{l}\text { - Train station } \\
\text { - Train } \\
\text { - On-campus }\end{array}$ & $\begin{array}{l}\text { - Facebook group } \\
\text { - Texting } \\
\text { - Twitter } \\
\text { - Blog posts }\end{array}$ & $\begin{array}{l}\text { http://youtu.be/ } \\
\text { sZs7V7a38RU }\end{array}$ \\
\hline Growing up & $\begin{array}{l}\text { - Home } \\
\text { - Suburban street } \\
\text { - School } \\
\text { - On-campus } \\
\text { Playground }\end{array}$ & $\begin{array}{l}\text { - Facebook group } \\
\text { - Twitter } \\
\text { - Blog posts }\end{array}$ & $\begin{array}{l}\text { http://youtu.be/ } \\
\text { fbhNarT4Y2c }\end{array}$ \\
\hline Wings & $\begin{array}{l}\text { - Study room } \\
\text { - Suburban street } \\
\text { - Diary shop } \\
\text { - School play group } \\
\text { - Garden }\end{array}$ & $\begin{array}{l}\text { - Texting } \\
\text { - Face-to-face } \\
\text { communication } \\
\text { - Blog posts }\end{array}$ & $\begin{array}{l}\text { http://youtu.be/ } \\
\text { 3a8A3kHP6mM }\end{array}$ \\
\hline Homeless & $\begin{array}{l}\text { - Hotel room } \\
\text { - City street } \\
\text { - Casino } \\
\text { - Texting }\end{array}$ & $\begin{array}{l}\text { - Twitter } \\
\text { - Facebook group } \\
\text { - Texting } \\
\text { - Blog posts }\end{array}$ & $\begin{array}{l}\text { http://youtu.be/ } \\
\text { 9p4sVkQVu-k }\end{array}$ \\
\hline
\end{tabular}

\section{Staff interview}

Lecturer R reflects on his experience in the project how the students used MW2.0 tools. According to Lecturer R, the quality of student work and communication skills demonstrated were comparatively better than that of the previous students he had taught. R observed that the students who were lacking in confidence in using new tools chose to work with the tools they were confident with, for example texting and Facebook:

Generally technically confident students took the lead in the class, their projects were more sophisticated and their communication (blogging, Tweeting and posting) was stronger.

Lecturer R's reflection on learning and teaching with MW2.0 tools provides an insight into the level of understanding he has gained in the process. He explains the importance of embedding the MW2.0 tools in the learning process and the importance of the staff modelling the use of the tools and technologies:

This experience [in the project] has certainly helped me work through ways of integrating these into a broader range of the courses activities along with developing MW2.0 tools 


\section{Narayan et al.}

into a broader range of course activities and at the same time develop strategies to minimize potential problems. One of the important things that came out of this was that these devices are that, just devices, and it is the process of integrating them into learning and teaching that is important. I believe that a key aspect of teaching is modeling. Teachers need to be able to model how technology is integrated into their teaching before students will adopt/accept it as part of their learning.

The Moving Image course will continue to encourage students to use their mobile devices. (Lecturer R-Moving Images)

Lecturer $\mathrm{C}$, who taught the DM course talks about her growth from participating in the project. The PAR methodology used in this project created room for the staff to grow its own knowledge from reflecting on their and their students' experience with the assistance of the researcher. Empowering, supporting and scaffolding staff development are the implicit elements woven into the PAR design of this project:

I think the most significant thing here was that I was keen to learn and being involved in the project has allowed me to up skill myself. The project gave me opportunities to gain embedded professional development.

Lecturer C outlines one instance where she found MW2.0 tools really useful. Lecturer $\mathrm{C}$ was sick at home but was able to still participate in the class activity. The MW2.0 tools enabled her to participate across the context boundary (classroom and home). $\mathrm{C}$ also evaluates the use of Twitter in the project against the former Spruz and explains with reasons how Twitter is a better fit for her course then Spruz:

... and the experience I had when I was unwell and Lecturer R carried out a practical filming exercise with students whilst I had contact via Twitter while at home sick.

In addition, for those students who have writing/learning disability, Twitter, with its 140 character limit can be a great benefit for scaffolding although a downside as it is highly public and therefore risky. The hashtag to create a community is really useful here as students can potentially create their own hashtags to develop specific discussions. I think Twitter is far better for this in some ways than a blogging site such as Spruz where conversations seems to become so visually complex and lacks the clarity of a "real life" conversation. (Lecturer C - Digital Media course)

\section{Discussion}

While the use of MW2.0 tools in the course was initially considered as a way to remedy the issues surrounding the lack of access time to specialist equipment for students to use, the design and implementation of its use in this project stretched the initial thinking. In considering the MW2.0 tools only as a remedy for plugging the issues, the staff were situating its use within traditional teaching practices hence failing to capitalise on the pedagogical affordances of MW2.0 tools. The design of this project focused on revisiting the processes (pedagogy) that embedding technology impacts on rather than just considering it as a solution to an existing problem. This added value for both the staff involved and had a positive impact on student learning.

\section{Content, context and learner-generated authentic context}

In evaluating the project outcomes against the 3Ps of Pedagogy 2.0 (participation, productivity and personalisation), all the groups chose to focus their work on real 
world issues and situations. The contexts they chose to work in were again situation within the real world environment and the varying choice of communicative tools used my students to suit their needs (Table 1) outlines the personalisation (learner choice and self-regulation) element of Pedagogy 2.0. The use of class hashtag on Twitter, a student-generated hashtag for collaborative purposes and student blogs highlighted the participatory (communication and collaboration) aspect of Pedagogy 2.0. The collaboration between students in groups to create the digital episodes, on Twitter and student blogs outlines the productivity (learner-generated content and creativity) element of Pedagogy 2.0.

The outcomes observed are mainly because of how MW2.0 tools were used and appropriated/personalised by the students to meet their needs and enhance their own learning experience, which was enabled by social constructivist pedagogies.

The use of MW2.0 tools encouraged students to be content creators rather than content consumers. Apart from listening to a lecture three times a week, the students through the use of MW2.0 tools were able to remix and remodel the concepts through collaboration with others and apply it to improve their own learning (McLoughlin and Lee 2007). While the ubiquitous nature of mobile devices combined with Web 2.0 tools enabled the bridging of learning context between the classroom and the "real world". It is the ability to enable students to work, learn and create within a context that is conducive to their own learning (learner-generated context) that has been highlighted in this project. Whitworth (2008) argues that when learning is situated in pre-determined learning contexts even when the design is underpinned by social constructivist pedagogies, students may still remain content consumers, where the observed student role is passive (Luckin et al. 2011). He further elaborates that the fast developing technologies and collaborative tools empower learners by giving them the ability to create a context for their own learning. This is where the role of a student is that of an active participant and content creator as observed in this study aided by the use of MW2.0 tools.

This is not to say the role of the teacher in student-generated context is unimportant; in fact in this study, the teachers were called upon for support often. Twitter combined with smart devices (iPhone and iPads in this case) acted as a "bridging agent" between student-generated contexts, the peers and teachers as sources for support and scaffold. The top tweeters in both the class hashtag and student-generated hashtags were the teachers. The high participation rate of the teachers in student-generated contexts and other online conservations highlight the support and scaffolding needed by students to progress through the zone of proximal development (Vygotsky 1978).

While more research is needed to explore how learner-generated context impacts on the learner and his/her learning, outcomes of this project have been positive. Student activities and feedback during the course indicated that they were better engaged in the learning process, the use of MW2.0 tools encouraged self-regulation, nurtured a sense of ownership, creativity and innovation in the learner.

\section{Issues with MW2.0}

The average age of the students in this project was 20 years, and according to Prensky (2001a, 2001b), these students would fall within the digital natives category meaning they are proficient in using technology and tools since they grew up being 


\section{Narayan et al.}

surrounded by it (Prensky, 2001a, 2001b). In this study, some students did not see any value in having an iPad/iPhone or using any other tool in their learning. The students who regularly attended the weekly technology sessions held by the researcher were observed to be active and effective users. The students who attended only the first session were the students who complained about not seeing any value of using MW2.0 tools in learning. It may be that they know how to use the devices and tools, but knowing how to apply this knowledge to improve your learning is certainly something the "digital natives" lacked in this study. The students' inability to apply their technological knowledge effectively for learning highlights the need for embedded scaffold and support in the process by the teachers.

\section{Where to from here?}

This pilot study has provided the staff valuable experience and positive outcomes for students in teaching and learning with MW2.0 tools. Currently in 2012 the courses are working with student owned devices and the teachers are considering making a portable device like an iPod a requirement for future enrolments.

\section{Conclusion}

This MW2.0 project has demonstrated an approach to professional development in the use of educational technologies and how it impacted on student learning. The use of MW2.0 tools provided the students with the flexibility and ability to choose a context that was conducive to their own learning. It enabled self-directedness but also collaborative learning, created space for student ownership in the learning process, student-generated context and content. It also provided the staff with an opportunity to reflect and re-evaluate their pedagogical practices and enhance their knowledge and skills about learning and teaching with MW2.0 tools.

\section{References}

Amiel, T. \& Reeves, T. (2008) 'Design-based research and educational technology: rethinking technology and the research agenda', Educational Technology \& Society, vol. 11, pp. 29-40.

Anderson, P. (2007) 'What is Web 2.0? Ideas technologies and implications for education', [online]. JISC. Available at: www.jisc.ac.uk/media/documents/techwatch/tsw0701b.pdf

Bender, B. (2003) 'Student-centered learning: a personal journal', EDUCAUSE, vol. 2003, pp. $1-12$.

Blaschke, L. M. (2012) 'Heutagogy and lifelong learning: a review of heutagogical practice and self-determined learning', The International Review of Research in Open and Distance Learning (IRRODL), vol. 13, pp. 56-71.

Cochrane, T. \& Bateman, R. (2010) 'Smartphones give you wing: pedagogical affordances of mobile Web 2.0', Australasian Journal of Educational Technology, vol. 26, pp. 1-14.

Dabbagh, N. \& Reo, R. (2011) 'Back to the future: tracing the roots and learning affordances of social software', in Web 2.0-Based e-Learning, eds M. J. W. Lee \& C. Mcloughlin, Information Science Reference, New York, pp. 1-20.

Kemmis, S. \& McTaggart, R. (1988) The Action Research Planner, Deakin University, Geelong.

Luckin, R. (2008) 'The learner centric ecology for resources: a framework for using technology to scaffold learning', Computers \& Education, vol. 50, pp. 449-462.

Luckin, R., et al. (2007) 'Learner-generated contexts: sustainable learning pathways through open content', OpenLearn07 Conference, Milton Keynes, October 2007.

Luckin, R., et al. (2008a) Learner Generated Contexts: A Framework to Support the Effective Use of Technology to Support Learning [online]. Available at: http://api.ning. 
com/files/Ij6j7ucsB9vgb11pKPHU6LKMGQQkR-YDVnxruI9tBGf1Q-eSYUDv-Mil6u WqX4F1jYA1PUkZRXvbxhnxuHusyL11RXVrBKnO/LGCOpenContextModelning.doc

Luckin, R., et al. (2008b) Learners' Use of Web 2.0 Technologies in and Out of School in Key Stages 3 and 4, Becta, Coventry.

Luckin, R., et al. (2011) 'Learner-generated contexts', in Web 2.0-based e-learning: Applying Social Informatics for Tertiary Teaching, eds M. J. W. Lee \& C. Mclouglin, Information Science Reference, New York.

McLoughlin, C. \& Lee, M. J. W. (2007) 'Social software and participatory learning: pedagogical choices with technology affordances in the Web 2.0 era', in ASCILITE, Singapore, pp. 664-675.

McLoughlin, C. \& Lee, M. J. W. (2008a) 'Future learning landscapes: transforming pedagogy through social software', Innovate Journal of Online Education [online], 4. Available at: http://innovateonline.info/pdf/vol4_issue5/Future_Learning_Landscapes-_Transforming_ Pedagogy_through_Social_Software.pdf

McLoughlin, C. \& Lee, M. J. W. (2008b) 'Mapping the digital terrain: new media and social software as catalysts for pedagogical change', ASCILITE, Melbourne, pp. 641-652.

McLoughlin, C. \& Lee, M. J. W. (2008c) 'The three P's of pedagogy for the networked society: personalisation, participation and productivity', International Journal of Teaching and Learning in Higher Education, vol. 20, pp. 10-17.

McNiff, J. (1988) Action Research: Principles and Practice, MacMillan Education, London.

O'Reilly, T. (2005) 'What is Web 2.0: design patterns and business models for the next generation of Software', [online]. Available at: http://www.oreillynet.com/pub/a/oreilly/tim/ news/2005/09/30/what-is-web-20.html

O'Reilly, T. \& Battelle, J. (2009) 'Web squared: Web 2.0 five years', Special Report for the Web 2.0 Summit [online]. Available at: http://assets.en.oreilly.com/1/event/28/web2009_ websquared-whitepaper.pdf

Prensky, M. (2001a) 'Digital natives, digital immigrants', On the Horizon [online], 9. Available at: http://www.marcprensky.com/writing/Prensky\%20-\%20Digital\%20Natives, \%20Digital\% 20Immigrants $\% 20-\% 20$ Part1.pdf

Prensky, M. (2001b) 'Do they really think differently?' On the Horizon [online], 9. Available at: www.marcprensky.com/.../prensky $\% 20-\% 20$ digital $\% 20$ natives, $\% 20$ digital $\% 20$ immigrants $\%$ 20-\%20part2.pdf

Reeves, T. (1997) 'Evaluating what really matters in computer-based education', in Computer Education: New Perspectives, eds M. Wild \& D. Kirkpatrick, MASTEC, Perth, pp. 219-246.

Saettler, P. (1990) The Evolution of American Educational Technology, Libraries Unlimited, Englewood, CO.

Siemens, G. (2005) 'Connectivism: a learning theory for the digital age', International Journal of Instructional Technology and Distance Learning, vol. 2, pp. 3-10.

Siemens, G. \& Matheos, K. (2010) 'Systemic changes in Higher Education', Technology and Social Media [online], 16. Available at: http://www.ineducation.ca/article/systemic-changeshigher-education

TLRP (2008) 'Education 2.0? Designing the web for teaching and learning', in , ed. N. Selwyn, Teaching and Learning Research Programme, London.

Vygotsky, L. S. (1978) Mind and Society: The Development of Higher Psychological Processes, Harvard University Press, Cambridge.

Vygotsky, L. S. (1986) Thought and Language, MIT Press, Cambridge, MA.

Whitworth, A. (2008) Learner-Generated Contexts: Critical theory and ICT education, 6th Hellenic Conference on ICT Applications in Education, Limassol, Cyprus, pp. 62-70. 